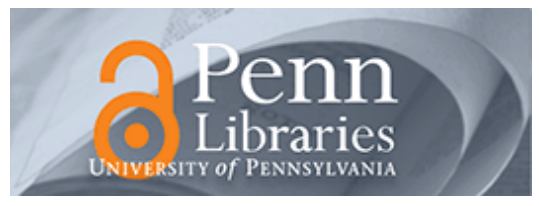

University of Pennsylvania

ScholarlyCommons

Accounting Papers

Wharton Faculty Research

2002

\title{
The Impact of Voluntary Corporate Disclosures on the Ex-Ante Cost of Capital for Swiss Firms
}

Luzi Hail

University of Pennsylvania

Follow this and additional works at: https://repository.upenn.edu/accounting_papers

Part of the Accounting Commons

\section{Recommended Citation}

Hail, L. (2002). The Impact of Voluntary Corporate Disclosures on the Ex-Ante Cost of Capital for Swiss Firms. European Accounting Review, 11 (4), 741-773. http://dx.doi.org/10.1080/0963818022000001109

This paper is posted at ScholarlyCommons. https://repository.upenn.edu/accounting_papers/33

For more information, please contact repository@pobox.upenn.edu. 


\title{
The Impact of Voluntary Corporate Disclosures on the Ex-Ante Cost of Capital for Swiss Firms
}

\author{
Abstract \\ The relationship between disclosure quality and cost of equity capital is an important topic in today's \\ economy. In general, economic theory and anecdotal evidence suggest a negative association. Empirical \\ work on this link, however, is confronted with major methodological drawbacks - neither disclosure level \\ nor cost of capital can be observed directly - and has documented somewhat confounding results so far. \\ Adopting a finite horizon version of the residual income model, I provide evidence on the nature of the \\ above relationship and try to quantify the effect of a firm's voluntary disclosure policy on its implied cost \\ of capital. Switzerland seems especially suited for an analysis of this kind given that Swiss firms have \\ considerable reporting discretion and the mandated level of disclosure is low. For a cross-sectional \\ sample of seventy-three non-financial companies I show a negative and highly significant association \\ between the two variables. The magnitude is such that the most forthcoming firms enjoy about a 1.8 to \\ $2.4 \%$ cost advantage over the least forthcoming firms. The findings persist even after controlling for other \\ potentially influential variables, e.g. risk characteristics and firm size. Furthermore, adjusting for self- \\ selection bias - a major concern in disclosure studies - the marginal effect remains of the same \\ direction and even increases in magnitude, although at lower levels of statistical significance. One reason \\ for the strong relationship might be found in differing institutional factors between the US and Swiss \\ capital markets.
}

\section{Keywords}

voluntary disclosure, disclosure quality, financial reporting, valuation, cost of capital, analysts' behaviour

\section{Disciplines}

Accounting 


\title{
The Impact of Voluntary Corporate Disclosures on the Ex ante Cost of Capital for Swiss Firms
}

\author{
Luzi Hail \\ Assistant Professor of Accounting \\ Institute for Accounting and Control \\ University of Zurich \\ 8032 Zurich - Switzerland \\ email: lhail@irc.unizh.ch
}

First draft: October 2000

Current draft: May 2002, forthcoming in European Accounting Review

\begin{abstract}
The relationship between disclosure quality and cost of equity capital is an important topic in today's economy. In general, economic theory and anecdotal evidence suggest a negative association. Empirical work on this link, however, is confronted with major methodological drawbacks - neither disclosure level nor cost of capital can be observed directly and has documented somewhat confounding results so far. Adopting a finite horizon version of the residual income model, I provide evidence on the nature of the above relationship and try to quantify the effect of a firm's voluntary disclosure policy on its implied cost of capital. Switzerland seems especially suited for an analysis of this kind given that Swiss firms have considerable reporting discretion and the mandated level of disclosure is low. For a crosssectional sample of 73 non-financial companies I show a negative and highly significant association between the two variables. The magnitude is such that the most forthcoming firms enjoy about a $1.8 \%$ to $2.4 \%$ cost advantage over the least forthcoming firms. The findings persist even after controlling for other potentially influential variables, e.g. risk characteristics and firm size. Furthermore, adjusting for self-selection bias - a major concern in disclosure studies - the marginal effect remains of the same direction and even increases in magnitude although at lower levels of statistical significance. One reason for the strong relationship might be found in differing institutional factors between the US and Swiss capital markets.
\end{abstract}

I gratefully acknowledge the helpful comments from David Burgstahler, Charles M.C. Lee, two anonymous reviewers and workshop participants at the University of Goettingen, Tilburg University, the University of Zurich, the University of Washington, the 2001 E $\Lambda \Lambda$ annual congress in $\Lambda$ thens, and the 2001 Euroconference FIRRE in Palermo. Special thanks to Christof Luchsinger and Ivan Koehle for their expert research assistance. I appreciate the contribution of $\mathrm{I} / \mathrm{B} / \mathrm{E} / \mathrm{S}$ International Inc. for providing earnings per share forecast data, available through the Institutional Brokers Estimate System. 


\title{
The Impact of Voluntary Corporate Disclosures on the Ex ante Cost of Capital for Swiss Firms
}

\begin{abstract}
:
The relationship between disclosure quality and cost of equity capital is an important topic in today's economy. In general, economic theory and anecdotal evidence suggest a negative association. Empirical work on this link, however, is confronted with major methodological drawbacks - neither disclosure level nor cost of capital can be observed directly - and has documented somewhat confounding results so far. Adopting a finite horizon version of the residual income model, I provide evidence on the nature of the above relationship and try to quantify the effect of a firm's voluntary disclosure policy on its implied cost of capital. Switzerland seems especially suited for an analysis of this kind given that Swiss firms have considerable reporting discretion and the mandated level of disclosure is low. For a crosssectional sample of 73 non-financial companies I show a negative and highly significant association between the two variables. The magnitude is such that the most forthcoming firms enjoy about a $1.8 \%$ to $2.4 \%$ cost advantage over the least forthcoming firms. The findings persist even after controlling for other potentially influential variables, e.g. risk characteristics and firm size. Furthermore, adjusting for self-selection bias - a major concern in disclosure studies - the marginal effect remains of the same direction and even increases in magnitude although at lower levels of statistical significance. One reason for the strong relationship might be found in differing institutional factors between the US and Swiss capital markets.
\end{abstract}

Keywords: Voluntary disclosure, Disclosure quality, Financial reporting, Valuation, Cost of capital, Analysts' behavior 


\section{Introduction}

The relationship between disclosure quality and cost of equity capital is an important topic in today's economy. In general, anecdotal evidence and the widespread perception of its role among practitioners suggest that disclosure policy is negatively related to a company's costs of equity financing. Theoretical research also supports the impact of greater disclosure to reduce cost of capital by emphasizing its effect on stock market liquidity and estimation risk. Empirical work on this relationship, however, is confronted with major methodological drawbacks and has documented somewhat confounding results so far. Neither disclosure level nor cost of capital can be observed directly and both variables rely heavily on individual perception rather than actual use. In addition, as most of the prior studies focus on data from publicly held companies in the US, whose disclosure environment is already rich, it might prove difficult to document the conjectured relation empirically. In order to strengthen empirical tests, recent studies such as Healy et al. (1999) or Leuz and Verrecchia (2000) concentrate on specific occasions and reporting contexts where one can observe large changes in disclosure policy, thereby hoping to render the presumably subtle effect of disclosure more easily detectable.

In accordance with this line of research, I therefore turn to a low disclosure environment trying to identify the impact of voluntary corporate reporting on a firm's implied cost of capital. Switzerland seems to be particularly suited for an analysis of this kind: the stock market displays many common attributes of a typical stock market in continental Europe and management's reliance on shareholder interests is a relatively new phenomenon. Moreover, Swiss firms have considerable reporting discretion and the mandated level of disclosure is low. The only requirement for stock listed companies is compliance with Swiss GAAP. Although frequently referred to as the local adaptation of internationally accepted accounting standards, it leaves the companies with a high degree of freedom in choosing their voluntary disclosure policy. For instance, any adoption of materially equal or better accounting standards (e.g. IAS or US GAAP) meets the listing criteria of the Swiss Exchange, and can be interpreted as a firm's commitment to greater disclosure. In response to their financial needs many Swiss firms voluntarily provide supplementary information within the context of Swiss GAAP. This specific research setting should make it easier to detect the economic consequences of an increased reporting strategy on a firm's cost of equity capital.

For a cross-sectional sample of 73 non-financial companies I show a negative and highly significant association between the two variables. As the coefficient on my disclosure score measured as fractional rank rather than absolute value - indicates the presence of about a $1.8 \%$ to $2.4 \%$ cost difference among the most and the least forthcoming firms, the findings are not only statistically significant but also economically relevant. The results hold even after taking into account various other firm characteristics, e.g. firm size, market beta and financial leverage. Adjusting for self-selection bias, the marginal effect of a firm's disclosure policy remains of the same direction and even increases in magnitude although at lower levels of statistical significance.

To assess a firm's disclosure quality, I focus on the amount of voluntary disclosure provided in the annual report. The disclosure index used in my study was developed by the Swiss 
Banking Institute at the University of Zurich and reflects three different kinds of voluntary reporting choice. To compute prospective cost of capital - the dependent variable - I adopt a finite horizon version of the accounting based valuation formula proposed by Gebhardt et al. (2000). Firm value, measured by stock price, is set equal to current book value plus future discounted residual income over a short-term period of explicit forecasts, a medium-term fading period and a long-term perpetuity. Solving for the implied discount rate gives us an estimate of the ex ante cost of equity capital without relying on realized stock return data.

The remainder of the paper is organized as follows. Section 2 briefly reviews prior research on the topic. In section 3, I develop the main hypothesis and describe the independent and dependent variables. Proxy selection, sampling procedures and descriptive statistics for sample firms are provided in section 4 . Section 5 assesses the validity of my measures of disclosure level and cost of equity capital and reports empirical findings. In section 6 specification tests are presented. Conclusions and suggestions for future research appear in section 7 .

\section{Related Research}

From a theoretical point of view two distinct lines of research support the hypothesis of a negative connection between disclosure level and cost of equity capital: a stock market liquidity and an estimation risk perspective. On the one hand, firms try to overcome the reluctance of potential investors for holding shares in illiquid markets by revealing private information and thereby reducing their cost of capital. For example, Diamond and Verrecchia (1991) construct a model in which disclosure improves future liquidity of a firm's securities by attracting increased demand from large investors, and this in turn reduces the firm's costs of equity financing, with large firms benefiting the most. ${ }^{1}$ This stream of research includes Glosten and Milgrom (1985), Amihud and Mendelson (1986) or Baiman and Verrecchia (1996) and is also supported by a recent experimental study from Bloomfield and Wilks (2000), who in a laboratory financial market show that improved disclosure quality leads investors to demand shares at higher prices (therefore implicitly lowering cost of capital) and to provide a greater degree of liquidity. On the other hand, firms try to reduce potential investors' estimation risk regarding the parameters of a security's future return or payoff distribution by providing better disclosure. If at least part of the estimation risk component is nondiversifiable, e.g. when investors have different information regarding individual securities, and low information assets constitute a nontrivial fraction of the final portfolios, then it should be priced by the market to some degree. For example, Handa and Linn (1993) show in their Arbitrage Pricing Theory model, that a Bayesian investor attributes more systematic risk to an asset with low information (e.g. poor disclosure) than to an asset with high information leading to lower demands and prices than under complete information. This line of research is represented by Klein and Bawa (1976), Coles et al. (1995) or Clarkson et al. (1996). In sum-

They further show that under certain, "less typical" conditions the reduction of information asymmetry can also have the opposite effect, implying a less-than-full-disclosure equilibrium. For a general discussion of the theoretical underpinnings and assumptions of the relation between disclosure and the cost of capital see e.g. Verrecchia (1999). 
mary, positive effects of improved financial reporting are sustained by accounting theory in two respects: (1) investors' preferences for securities with potentially small transactions costs when executing future trades and (2) investors' preferences for securities with a relatively lower level of uncertainty about future returns or payoffs. ${ }^{2}$

Empirical support for the suggested link comes from a growing body of recent studies. In most cases the authors try to relate corporate disclosures and the information asymmetry component (or some information risk premium) and not the entire cost of capital, as this procedure offers a more direct test of the predicted association. For example, Welker (1995) and Sengupta (1998) document a significant negative relation between financial analysts' disclosure rankings and a firm's bid-ask spread as well as its interest cost of issuing debt, respectively. Healy et al. (1999) show that firms with significant and sustained improvements in voluntary disclosure experience improved stock performance and capital market intermediation. For a sample of German firms, Leuz and Verrecchia (2000) document that an international reporting strategy (IAS or US GAAP) in contrast to local GAAP is associated with lower bid-ask spreads and higher share turnover after controlling for various firm characteristics other than disclosure policy. In other kinds of studies, researchers focus on a single type of disclosure. Marquardt and Wiedman (1998), for example, provide evidence that managers - by their discretion to issue earnings forecasts ahead of selling their own stocks through a secondary equity offering - act as if increased voluntary disclosure and reduced information asymmetry correlate with a reduced cost of capital. Clement et al. (2000) investigate the capital market's reaction to the release of confirming earnings forecasts and find a significant positive relationship in combination with a reduction in earnings uncertainty.

An alternate way of testing the above relation is looking at the entire cost of capital instead of concentrating on the information asymmetry component. Although this approach is likely to introduce some noise, it offers the advantage of estimating the magnitude of the disclosure effect on a firm's discount factor. Probably the first attempt to establish such a direct link was made by Botosan (1997). From a sample of 115 firms from the machinery industry she demonstrated that among firms attracting a low analyst following, those with higherquality disclosures (as measured by her own disclosure index) benefited from lower costs of capital (as measured implicitly by a version of the residual income model). In Botosan and Plumlee (2000) the basic research methodology is extended to include a larger, multi-industry sample over several consecutive years, three different types of disclosures and four alternate estimates of cost of equity capital. The findings - albeit at the 5 to $8 \%$ level of statistical significance - suggest that greater disclosure provided through a company's annual report is associated with a lower cost of capital after controlling for firm size and market beta. ${ }^{3}$ In the

2 The proprietary nature of disclosure often limits the amount and quality of information actually disclosed, e.g. when facing imperfect product market competition or potential entry. For analytical models explicitly incorporating the costs of increased disclosure see e.g. Verrecchia (1983), Darrough and Stoughton (1990), Verrecchia (1990), and Wagenhofer (1990).

3 For the other disclosure categories included in the analysis (e.g. other publications, investor relations and total disclosure score) somewhat confounding results are reported in that either none or a positive relation is 
following, I adopt a similar technique to Botosan (1997) because of its intuitive appeal to make the effects of an improved reporting strategy more visible. As her results may suffer from self-selection bias, however, potential endogeneity of the disclosure variable has to be taken into account.

For reasons of disclosure regulations I focus on the capital market in Switzerland. Empirical evidence, however, on the relationship between disclosure practices and capital market characteristics in a Swiss environment is scarce. For example, in examining the determinants of the voluntary disclosure behavior of Swiss listed firms, Raffournier (1995) shows that large and internationally diversified companies tend to provide more information in their annual reports than small, purely domestic enterprises. Auer (1998) does not find a statistically significant impact on the variance of stock returns and market beta when a firm switches from lower-quality Swiss GAAP to presumably higher-quality international reporting standards, but documents a significant increase in the variance of abnormal returns around earnings release dates induced by the change. Finally, Caramanolis et al. (1999) try to relate stock price abnormal reactions subsequent to the release of annual reports to financial analysts' perception of disclosure quality and the number of analysts following a given firm. They find an asymmetric relationship in that positive abnormal returns are positively related to the disclosure rating variable (signaling hypothesis), while negative abnormal returns are inversely affected by analyst coverage (adverse selection hypothesis) but not vice versa.

\section{Hypothesis Development and Research Design}

\section{Hypothesis development}

As outlined above, anecdotal evidence, economic theory and empirical research suggest that increasing disclosure levels should reduce the estimation risk and information asymmetry components of a firm's cost of capital. Whereas the former works via improving forecast accuracy of a security's future return or payoff distribution, the latter works via diminishing information disparities among traders thereby augmenting liquidity. This reasoning motivates the following hypothesis (stated in alternative form):

$\mathrm{H}_{\mathrm{a}}$ : There is a negative association between the quality of corporate disclosures and the expected cost of equity capital.

The major difficulty in documenting this relationship empirically is fourfold: (1) the quality of corporate disclosures can not be assessed objectively and relies heavily on the perception and not the actual use of disclosure either by the researcher or by some peer user group; (2) firms might not choose disclosure level independently, which makes the variable subject to self-selection bias; (3) there is no direct measure of the firm's prospective cost of capital nor of its components; (4) the relationship between disclosure level and the market's profit-

found. Botosan and Plumlee (2000) argue that more timely disclosures might attract short-term investors leading to an increase in stock price volatility and thus, higher instead of lower cost of equity capital. 
ability expectations might be weak or confounded by several other factors so that no significant association is found. The research design attempts to cope with each of these concerns.

\section{Independent variable: Quality of Corporate Disclosures}

The purpose of my disclosure variable is to produce a reliable cross-sectional ranking of disclosure level among different firms. While Swiss accounting law and Swiss GAAP provide a minimum standard for Swiss listed companies, considerable latitude remains in what information is actually disclosed. Management has the discretion to voluntarily provide more than the mandatory requirements, e.g. earnings and sales forecasts, value-based performance measures, information on executive compensation schemes or qualitative discussion of the firm's business strategy. This kind of discretionary behavior does not - as often suggested by public opinion - necessarily assume that someone is being "fooled". Rather, it can be viewed as the management communicating its superior information to outside investors and is therefore the natural manifestation of multi-period contracting in an incomplete market (see Watts and Zimmerman, 1986). This reasoning provides several motivations for voluntary disclosure such as overcoming the adverse selection problem, reducing transaction costs in capital markets or avoiding future legal costs from stockholder proxy suits.

To assess a firm's disclosure quality I focus on the amount of voluntary disclosure provided in its annual report. The restriction to a single source of corporate information, although quite rigid, offers several advantages: annual reports are generally considered the most important information source for financial analysts and investors in making their investment choice. Timing differences are minimized as most companies release their annual reports within three months after the end of the fiscal year, usually December 31 . Given their formalized structure, annual reports are more easily comparable among firms than other, less formal communication channels like press releases or direct contact with analysts. Furthermore, empirical research indicates a positive correlation between information dispersed by annual reports and other types of communication (Lang and Lundholm, 1993), suggesting that firms coordinate their overall disclosure policy. However, caution should be used in interpreting the results: to the same extent that several means of communication are positively correlated, the marginal effect of voluntary annual report disclosures is likely to be overstated. No attempt is made to disentangle these overlapping forces. Rather than the annual report alone, the results are likely to reflect the outcome of a whole bundle of voluntary disclosures provided by the firm. In addition, the measurement of disclosure level needs some sort of benchmark to compare against and the definition of criteria to assess its informativeness. In every case, the selected items imply a certain level of subjectivity that may (or may not) reflect the actual use of information by investors.

As suggested by several recent studies (e.g. Welker, 1995; Harris and Muller, 1999; Leuz and Verrecchia, 2000) there might exist an endogeneity problem in determining the association between cost of capital and disclosure policy. Specifically, if firms purposefully choose their reporting strategy considering the costs and benefits of increased disclosures, the analysis of the above relationship might suffer from self-selection bias. For instance, companies that opt for a high disclosure environment might differ from those that do not in terms of firm characteristics and hence may have lower costs of capital regardless. In the presence of en- 
dogeneity, ordinary least squares (OLS) regression is likely to produce inconsistent estimators. Therefore, sensitivity tests are conducted using a two-equation model in which both, cost of equity capital as well as disclosure level, appear as endogenously selected: (1) in an attempt to represent the firm's reporting decision, disclosure quality is modeled as a function of several firm characteristics identified in prior research, and (2) cost of capital is modeled as a function of - among others - the firm's voluntary disclosure choice thereby explicitly taking into account the endogenous nature of this variable. The two-equation approach is then estimated utilizing two-stage least squares (2SLS) in order to control for potential self-selection bias.

\section{Dependent variable: Ex ante Cost of Capital}

To compute the ex ante cost of capital I adopt a version of the accounting based valuation formula often referred to as the residual income model. ${ }^{4}$ In this model firm value is represented as a function of current and forecasted accounting data subject only to the clean surplus relation, that is, all future changes in book value arise either from earnings, capital contributions or dividends. Using the residual income model I then compute the ex ante cost of capital as the internal rate of return that equates the intrinsic value of the firm to the current stock price.

The derivation of the residual income model starts with the dividend discount formula, which is standard in neoclassical models of security valuation. It states that the implied market price of a firm's stock is equal to the present value of future expected dividends:

$$
V_{t}=\sum_{\tau=1}^{\infty} E_{t}\left[\frac{d_{t+\tau}}{(1+r)^{\tau}}\right]
$$

$$
\begin{aligned}
& \text { where } \quad V_{t}=\text { "intrinsic" value of the firm at date } \mathrm{t} \\
& d_{t} \quad=\quad \text { net dividends paid during period }(\mathrm{t}-1, \mathrm{t}) \\
& r=\text { discount rate } \\
& E_{t}[.]=\text { expected value operator conditioned on information available } \\
& \text { at date } \mathrm{t}
\end{aligned}
$$

This definition assumes a flat term-structure of either the cost of risky equity capital or the risk-free discount rates. ${ }^{5}$ Under the assumption of clean surplus accounting, that is:

$b v_{t}=b v_{t-1}+x_{t}-d_{t}$

where $\quad b v_{t}=$ accounting book value of equity at date $\mathrm{t}$

4 The relation expressed in this model, although not new, gained vast attention among researchers and for practical use with the theoretical work of Ohlson (1995) and Feltham and Ohlson (1995). Earlier analytical treatment can be found in Preinreich (1938), Lücke (1955), Edwards and Bell (1961), and Peasnell (1982).

5 Although Ohlson (1995) and Feltham and Ohlson (1995) develop their model by discounting the riskadjusted arguments at the risk-free rate, no additional assumptions are required to restate it in terms of unadjusted dividends or earnings, respectively, discounted at the cost of risky equity capital (Bernard, 1995). 


$$
x_{t} \quad=\quad \text { accounting earnings for period }(\mathrm{t}-1, \mathrm{t})
$$

I then impose a restriction on the relation between accounting earnings, book value and dividends through time. Solving the clean surplus relation in (2) for dividends and combining it with the dividend discount formula in (1) yields, after some algebraic manipulation, the residual income model:

$$
V_{t}=b v_{t}+\sum_{\tau=1}^{\infty} E_{t}\left[\frac{x_{t+\tau}-r \cdot b v_{t} \tau-1}{(1+r)^{\tau}}\right]=b v_{t}+\sum_{\tau=1}^{\infty} E_{t}\left[\frac{\left(P R O F_{t+\tau}-r\right) b v_{t \tau-1}}{(1+r)^{\tau}}\right]
$$

where $\quad P R O F_{t}=$ after-tax return on book value of equity for period $(\mathrm{t}-1, \mathrm{t})$

Firm value equals reported book value plus an infinite sum of discounted residual income and is expressed entirely as a function of accounting numbers, namely expected future earnings and current and expected future book values. No explicit reference to dividends is needed. It is important to note that, as it stands, equation (3) is just the residual income version of the dividend discount model. It holds regardless of the accounting method used, even if the reported numbers are manipulated.

In an efficient market the intrinsic value $V$ at date $\mathrm{t}$ equals the market price $P$ of a firm's stock at date t. Using this relationship and solving, by an iterative process, for the implied discount rate produces an estimate of the ex ante cost of capital conditioned on the currently available information. I now turn to the empirical implementation of the model outlined above.

\section{Empirical Implementation}

To measure the firm's intrinsic value, equation (3) requires forecasting future earnings and book values to infinity. Practical valuation analysis, however, calls for accounting numbers to be forecasted over finite horizons. This truncation necessarily involves terminal value calculations based on assumptions about the time-series properties of future residual income. Similar to Lee et al. (1999) and Gebhardt et al. (2000) I adopt a three-stage approach to compute intrinsic value: first, I use explicit earnings forecasts for the next three years; second, I derive earnings forecasts by linearly fading year $t+3$ after-tax return on book value of equity to the median market return on equity by year $\mathrm{t}+\mathrm{T}$, and third, I calculate terminal value by assuming the latest residual income as a perpetuity. This leads to the following finite horizon specification:

$$
\begin{aligned}
& P_{t}=b v_{t}+\sum_{\tau=1}^{n} \frac{\left(\hat{x}_{t+\tau}-r_{e} \cdot b v_{t} \tau_{-1}\right)}{\left(1+r_{e}\right)^{\tau}}+\sum_{\tau=n+1}^{T} \frac{\left(\hat{x}_{t+\tau}-r_{e} \cdot b v_{t} \tau-1\right.}{\left(1+r_{e}\right)^{\tau}}+\frac{\left(\hat{x}_{t+T+1}-r_{e} \cdot b v_{t \tau}\right)}{r_{e}\left(1+r_{e}\right)^{T}} \\
& \text { where } \begin{array}{ll}
P_{t}= & \text { market price of a firm's stock at date } \mathrm{t}
\end{array} \\
& \hat{x}_{t+\tau}=\quad \begin{array}{l}
\text { expected future accounting earnings for period }(\mathrm{t}+\tau-1, \mathrm{t}+\tau), \\
\text { either explicitly forecasted, generated by a linear fading rate } \\
\text { or assumed constant }
\end{array} \\
& \begin{array}{ll}
r_{e}= & \text { estimate of the ex ante cost of capital calculated as the inter- } \\
& \text { nal rate of return to solve the equation }
\end{array}
\end{aligned}
$$




$$
\begin{aligned}
b v_{t+\tau}= & \text { expected future accounting book value of equity at date } \mathrm{t}+\tau, \\
& \text { where } b v_{t+\tau}=b v_{t+\tau-1}+\hat{x}_{t+\tau}-\hat{d}_{t+\tau} \text { and } \hat{d}_{t+\tau}=\text { expected future } \\
& \text { net dividends for period }(\mathrm{t}+\tau-1, \mathrm{t}+\tau), \text { derived from the divi- } \\
& \text { dend payout ratio } k \text { times the earnings forecast } \hat{x}_{t+\tau}
\end{aligned}
$$

Current stock price is set equal to current book value plus discounted residual income over a short-term period of explicit forecasts, a medium-term fading period and long-term perpetuity with no further growth. This disaggregation along the timeline attempts to capture our superior knowledge about the near-term future as well as the effect of dissipating economic rents within a forecast horizon of reasonable length (see Bernard, 1994).

Despite its intuitive appeal, the suggested empirical model is far from indisputable. In order to calculate future residual income, estimates of future book values and, consequently, of future dividends are required. This leaves us in much the same position as with the dividend discount model. It can be shown that the above finite horizon valuation model is just a special case of forecasting dividends up to period $\mathrm{t}+\mathrm{T}$ in combination with an appropriate terminal value calculation (Penman, 1997; Dechow et al., 1999). Thus, intrinsic value can be rewritten as explicit forecasts of dividends for the near-term and medium-term future and dividends are assumed to equal accounting earnings thereafter. No further reference to current book value of equity is needed. A second concern relates to the linear information dynamics in either Ohlson (1995) or Feltham and Ohlson (1995) that deals with the time-series behavior of abnormal earnings. No such restriction on the relation between current information and future residual income is considered (see Myers, 1999).

The implementation of the residual income model in (3) as a stepwise function in (4) puts the emphasis on the explicit forecast period. Because

$$
V_{t}^{T} \rightarrow P_{t} \text { as } T \rightarrow \infty
$$

where $\quad V_{t}^{T}=$ intrinsic value of the firm at date $\mathrm{t}$ as a function of future earnings and book values measured over a finite horizon

the proxy of intrinsic value approaches the current market price of the firm's stock, so long as the forecast horizon is just "long enough" (Bernard, 1995). Thus, the usefulness of the selected research procedure ultimately rests on an empirical question. As Penman and Sougiannis (1998) show, valuation errors are lower using accrual earnings techniques rather than cash flow or dividend discounting techniques over forecasting horizons as reasonable within one to eight years. ${ }^{6}$ In the remainder I relate the empirical estimate of the ex ante cost of capital to my measure of disclosure quality and assess its validity in various specification tests.

6 Contrary to Penman and Sougiannis (1998), I empirically adopt the residual income model based on actual forecasts, not on ex post realizations. 


\section{Input Data, Sample Selection and Description}

\section{Proxies for Disclosure Quality}

The disclosure score DISC relies on a study conducted by the Swiss Banking Institute (SBI) at the University of Zurich and published in "Bilanz", a Swiss economic and business monthly. The index is based on the voluntary information companies provide with respect to Swiss GAAP in their 1997 annual report to shareholders, which leaves the management with enough discretion in determining a firm's reporting strategy. Ideally, one would identify the difference between all information items disclosed in annual reports and those whose disclosure is mandatory. Since this procedure seems unrealistic, SBI chose to question primary users of financial statements on voluntary disclosure items they considered informative in their decision making process. However, any list of items is subject to selection bias and can be criticized. Testing the validity of disclosure scores hence becomes critical.

Disclosure quality is assessed using a value reporting scorecard and assigning points to predefined criteria. The selection of items included in the scorecard was guided by financial analysts' and investors' informational needs identified in prior research (e.g. Botosan, 1997), in anecdotal evidence, in a survey among Swiss institutional investors and financial analysts, and in interviews with a peer user group. Three categories of voluntary disclosure are recognized: (1) background and non-financial information, such as principal products and markets and organizational structure or operational efficiency, to provide insights into a firm's competitive environment and into its performance where not properly reflected in current financial statements; (2) trend analysis and management discussion and analysis, such as sales trends over the last several years and qualitative discussion of last year's change, to allow investors to evaluate a company's financial history; (3) risk, value-based and projected information, such as risk exposure, management compensation or earnings forecasts, to assess management's contribution to create shareholder value and to enlighten the firm's future prospects. Appendix A summarizes the major elements included in the disclosure index. Each item scores two points if there is a detailed description including e.g. quantified information or qualitative discussion, one point if it is mentioned in annual reports but only generally and zero otherwise. No weighting is used so that the overall score represents a simple summation of its components suggesting that every item analyzed is equally important. If a company reports all the requested data, a total of 54 points is assigned. I perform my analysis using the fractional rank of a firm's disclosure score as it is less sensitive to the influence of outliers and makes the regression coefficients easier to interpret. Using absolute disclosure values instead does not qualitatively change the results. DRANK is computed by dividing the rank of DISC by the number of firms in the sample and increases with disclosure quality.

\section{Proxies for Ex ante Cost of Capital}

To implement the finite horizon specification of the residual income model, stock prices and several proxies of current and future accounting numbers are needed. Specifically, I choose June 30, 1998, as the observation date to ensure that the analysis is based solely on publicly available information. By that point all the companies in the sample had released their annual reports for fiscal year 1997 so that disclosure quality should be reflected by the 
market. As the current market price is set equal to the intrinsic value, care should be used in selecting an adequate price for a firm's stock. Instead of arbitrarily choosing the closing price of a single day I use the equally weighted average for the month of June as market proxy. ${ }^{7}$ This procedure accounts for the sequential release of annual reports and corresponds to the analysts' forecast data, which also represent the entire month of June rather than a specific date. The following valuation formula is estimated for each firm:

$$
\begin{aligned}
& P_{t}=b v_{t}+\sum_{\tau=1}^{3} \frac{\left(\hat{x}_{t+\tau}-r_{e} \cdot b v_{t \tau-1}\right)}{\left(1+r_{e}\right)^{\tau}}+\sum_{\tau=4}^{12} \frac{\left(\hat{x}_{t+\tau}-r_{e} \cdot b v_{t}+1\right)}{\left(1+r_{e}\right)^{\tau}}+\frac{\left(\hat{x}_{t+13}-r_{e} \cdot b v_{t+12}\right)}{r_{e}\left(1+r_{e}\right)^{12}} \\
& \text { where } \quad P_{t}=\text { equally weighted stock price for the month of June } \\
& b v_{t}=\text { accounting book value per share at the beginning of the fiscal } \\
& \text { year } \\
& \hat{x}_{t+\tau}=\text { I use analysts' consensus forecasts and the mean long-term } \\
& \text { earnings growth rate as of June to calculate one-, two- and } \\
& \text { three-year-ahead earnings per share; beyond year } \mathrm{t}+3 \text {, earn- } \\
& \text { ings are forecasted by linearly fading actual return on book } \\
& \text { value of equity to the median market return on equity by year } \\
& \mathrm{t}+12 \\
& r_{e} \quad=\quad \text { internal rate of return } \\
& b v_{t+\tau}=\text { expected future accounting book value derived from clean } \\
& \text { surplus; future net dividends are estimated using the firm's } \\
& \text { average dividend payout ratio over the last five years }
\end{aligned}
$$

Analysts' most recent consensus forecasts serve as best proxies of accounting earnings for the first two fiscal years. ${ }^{8}$ For fiscal 2000 future expected earnings are derived by multiplying one plus the estimated long-term earnings growth rate with two-year-ahead earnings forecasts. Where no or only a single estimate is available the expected median sample growth rate is used instead. To compute book values, quite rigid assumptions are placed on the estimate of future dividend payout. For lack of better data, net dividends are estimated as a constant ratio of expected future earnings up to the finite forecast horizon and - assuming no more growth in later periods as is common in residual value calculation - set equal to $t+T$ earnings thereafter. The dividend payout ratio is defined as a historical mean adjusted for unusual observations (e.g. observations outside the range of 0 and 1). The explicit forecast horizon is fixed and consists of 12 future periods, which may be too short for growth firms and too long for mature firms. ${ }^{9}$ Target accounting return on equity of $8.98 \%$ is calculated as the median of past

7 I also estimate the cost of capital proxy using the closing price of June 30,1998 , instead of the monthly average. The test results are insensitive to alternative price specification.

8 There exists a broad range of studies that show analysts' superiority relative to univariate time-series models in predicting future earnings (e.g. Brown and Rozeff, 1978; Fried and Givoly, 1982; O'Brien, 1988) so that their estimates proxy for future expected earnings in my valuation model.

9 I also compute the implied cost of capital using $\mathbf{T}=9$ or 15 without materially changing the main results. 
returns from all Swiss listed companies over the last five years. I do not, however, adjust for industry specific returns as the Swiss market is generally too small and industry classification becomes rather arbitrary. ${ }^{10}$

Appendix B shows a more detailed illustration of the valuation model. Equity prices and accounting numbers are provided by Datastream (except for 8 firms where accounting data is handcollected based on Datastream definitions), earnings forecasts and analyst data are collected from the $\mathrm{I} / \mathrm{B} / \mathrm{E} / \mathrm{S}$ International database. ${ }^{11}$

\section{Sample Selection}

In their 1997 study of disclosure quality, SBI limited their analysis to the 50 highest capitalized Swiss companies plus another 61 randomly chosen smaller companies including some non-listed firms. This sampling procedure suggests a positive bias in disclosure quality since disclosure levels exhibit a positive correlation with market value (Lang and Lundholm, 1993). Disclosure costs tend to decrease with firm size and the information environment is generally assumed to be richer for large firms in terms of analyst and media coverage. As long as a sufficient cross-sectional variation in the disclosure score remains, the empirical analysis should not suffer from this deficit. Out of the 111 firms with disclosure score DISC available, 16 are dropped because of lack of stock and forecast data. Another 4 data sets are excluded by limiting the sample to firms whose fiscal year ends on December 31 (the majority) or during the first three months of the year. This criterion ensures that annual reports are publicly available by the end of June and stock prices have already incorporated the new information. Contrary to Botosan (1997), my sample is not restricted to companies from a single industry although I exclude 18 firms from the banking and insurance sector. Disclosure practices of financial institutions are strongly influenced by regulatory requirements and their business (and especially their business' recognition in financial statements) differs heavily from other industries. This suggests a systematic bias in disclosure quality, e.g. for risk information, and financial leverage (my proxy for financial risk as outlined below). ${ }^{12}$ As shown in table 1 , the sample selection procedure yields a final sample of 73 non-financial companies listed on the Swiss Exchange SWX.

\section{Descriptive statistics}

Descriptive statistics for the sample are provided in table 2 . The various measures associated with size - market value of outstanding equity (MARKET), book value of total assets

10. In additional analyses not reported the sample is split into industrial firms $(\mathrm{n}=52)$ and service firms $(\mathrm{n}=$ 21) using each subgroup's median of past accounting returns on equity as target ratio to calculate the implied cost of capital for the corresponding companies in the entire sample. This alternate specification does not affect the results.

11 To ensure consistency and to check my understanding of Datastream definitions, I compared handcollected data with original data provided by Datastream for several firms.

12 Including banking and insurance companies in the sample does not change the major empirical findings although the results are generally weaker and specification tests are more dependent on a single set of observations. 
(ASSET), total sales (SALES) and the number of employees (NEMP) - indicate a substantial cross-sectional variation in firm size. Market value of equity ranges from $27 \mathrm{CHF}$ million for the smallest to $151.8 \mathrm{CHF}$ billion for the largest firm in the sample. Mean (median) value is 6.3 CHF billion (661 CHF million). Including companies from the banking and insurance industry would intensify the disparity among firms even more. Leaving the median value quasi-unchanged, the sample mean would increase to $7.7 \mathrm{CHF}$ billion.

Risk, another important firm characteristic, is measured in two different ways. First, market beta of the stock (BETA) is estimated based on a two-year market model regression on the Swiss Performance Index SPI requiring at least 24 weekly return observations. Mean (median) value of $0.63(0.61)$ is notably below the theoretical value of one, indicating a systematic bias in the beta estimates. Only 11 out of 73 values surpass the presumed risk measure of the market as a whole. The results could be driven by several factors: every empirical test involving beta is also a test of its theoretical underpinnings. If the basic assumptions of the capital asset pricing model CAPM do not hold for the Swiss market because of market size or market structure, the resulting beta will be biased. Small firms, for instance, suffer from nontrading effects that underestimate beta values. Furthermore, beta coefficients based on historical data might be a poor proxy for future expected values. Schultz and Zimmermann (1989) show high inter-temporal variation in beta estimates for Swiss stocks, suggesting adjustments to account for beta's mean-reverting property. However, for the results reported below the unadjusted version of market beta is used, as is common practice in accounting literature. ${ }^{13}$ This procedure takes into account that - by looking at relative values - bias in beta estimates is not, by itself, a problem as long as the bias is consistent across all firms. Second, financial leverage (LEV) defined as the ratio of total debt to market value of outstanding equity is used as proxy for a firm's riskiness (see Modigliani and Miller, 1958). The higher a company's relative debt position, the more likely it will face financial distress from defaulting on interest and principal payments. Although the median value of 0.35 is considerably low, 12 observations exhibit financial leverage of one or more.

To assess a firm's disclosure environment, I apply two variables: the number of analysts following a specific firm (ANALYST) and my measure of disclosure quality (DISC). The average sample firm is followed by approximately 11 analysts. One quarter of the firms attract the attention of 7 or fewer analysts compared with the firms in the upper quartile which are followed by 15 or more persons. Three companies - Ciba Specialty Chemicals, Roche and Sika, all from the chemicals and pharmaceutical industry - receive the highest disclosure score of 30 points. They provide essential information on company background, key nonfinancials, value-based metrics and trend data, respectively, but still leave enough room for further improvement (fulfillment rate: $56 \%$ of overall score). On the other hand, Affichage Holding, an advertising and placard company, achieves a total of 7 points. Minimal background, non-financial and trend information is given in combination with a poor discussion of

13 For a subsample of 46 observations I also conduct the analysis using Blume (1975) estimates of beta coefficients which correct for estimation error and long-term trends in betas towards one. $\Lambda$ s expected, the mean and median values are significantly higher than without correction (e.g. 0.84 and 0.85 , respectively). The results of the subsequent analysis, however, seem not to be affected by the choice of unadjusted betas. 
changes in sales and operating income. The standard deviation of 5.6 points indicates a substantial amount of variation in the underlying annual reports.

Finally, ROE marks my estimate of future expected cost of equity capital as described above. The mean (median) value is $6.18 \%(6.06 \%)$ and the inter-quartile range of approximately $2 \%$ indicates a relatively tight distribution. Although $6.18 \%$ may appear low at first sight, it could be reasonable. With an actual (risk-free) yield on the 10 -year federal government bond on June 30,1998 , of $3.08 \%$, an average historical risk premium for the Swiss market of approximately $5 \%$ (e.g. Auer, 1998), and the sample average beta of 0.63 the CAPM generates a crude ex ante cost of capital estimate of $6.23 \%$. Moreover, current research by Claus and Thomas (1999) and Gebhardt et al. (2000) suggests that the implied risk premium for the market might be significantly lower than the traditional estimate obtained from ex post realized returns. In any event, the objective of my study is not to explain the absolute level of ex ante cost of equity capital, but to demonstrate cross-sectional variation in a firm's cost of capital conditional on differing disclosure quality.

\section{Empirical Results}

\section{Validity of Disclosure Score}

Corporate financial reporting is not easily evaluated because the development and application of a disclosure score relies heavily on a person's subjective perception and not on the actual use of disclosure. I therefore assess the validity of my disclosure measure DISC in two different ways: (1) since reporting strategies are coordinated across various avenues, the components of a disclosure index should exhibit a positive relationship with one another, and (2) disclosure scores should be associated with other firm characteristics identified in prior research that proxy for disclosure level. I use the results of a Pearson correlation analysis presented in table 3 to address these issues.

First, I assess the relationship between the overall company disclosure score DISC and its three components (DISC_1, DISC_2 and DISC_3). Each correlation coefficient is positive and, with one exception, highly significant. The coefficients among the components themselves are considerably lower than the ones involving DISC. I therefore suggest that the three categories may capture different aspects of disclosure. Nonetheless, they are still well represented by the firm's grand total.

Second, I examine several other variables where a relationship with disclosure level has already been shown empirically (e.g. Lang and Lundholm, 1993; Raffournier, 1995; Ahmed and Courtis, 1999): the number of analysts following a specific firm (ANALYST), market value of outstanding equity (MARKET), current profitability level measured as average realized accounting return on equity over the preceding five years (RETURN), listing status captured by a categorical variable set equal to one if the firm's shares are multiple listed and zero otherwise (LIST), financial leverage (LEV), and audit firm size, another categorical variable set equal to one if the firm is audited by a "Big Six" company and zero otherwise (AUDIT). In general, these firm characteristics have been hypothesized to be positively related to disclosure level, with corporate size and stock listing status yielding the most conclusive results. 
Explanations for this behavior include agency and political costs, corporate governance, signaling, audit firm reputation or capital needs. Consistent with prior research ANALYST, MARKET, LIST and AUDIT exhibit a positive and highly significant correlation with disclosure quality. Information should be more easily available for large firms and stocks with greater analyst coverage, companies listed internationally provide better disclosures than their Swiss-listed only counterparts, and large, well-known auditing firms play an important role in improving their clients' reporting strategy. The same holds true for the RETURN variable, albeit at a $10 \%$ level of statistical significance (two-tail test). Only LEV, my proxy for financial leverage, does not show a significant association. It seems that highly leveraged Swiss firms do not seek to reduce their monitoring costs by disclosing more information, at least in an univariate setting. ${ }^{14}$ Taken together, the validity of DISC as a measure of voluntary disclosure is generally supported by the above analyses. The same firm characteristics - apart from analyst following - are used later to form a disclosure model in the 2SLS approach attempting to incorporate self-selection.

\section{Validity of Ex ante Cost of Capital}

A valid measure of ex ante cost of equity capital should increase with risk and also display the well known "size effect". Risk is captured by a firm's market beta and market leverage, size by its market capitalization. Table 4 shows the results of an OLS regression analysis of my cost of capital estimate ROE on BETA, LEV and the natural log of MARKET. To minimize the influence of outliers, data for financial leverage is winsorized at the upper and lower $5 \%$ of observations and $\log$ transformations are used for market value.

The capital asset pricing model CAPM suggests a stock's market beta should be positively correlated with its cost of capital. Except for the simple regression in panel A, which has no explanative power at all, the results are consistent with this conjecture. Especially when including BETA and MARKET jointly the coefficient on a firm's systematic risk metric is positive and significant, whereas in the complete model the significance level increases to $12 \%$. This positive but rather weak relation could be caused by several reasons: from a theoretical point of view, the inclusion of both BETA and LEV is somewhat inconsistent. Market beta is supposed to be a function of the firm's financial leverage and hence should account for differences in financial risk. Theory would therefore suggest using unlevered betas in combination with financial leverage. For ease of comparison and as both variables are subject to separate estimation errors, my analysis relies on unadjusted betas. ${ }^{15}$ Dividing the sample by market value into two groups yields further insights. Whereas the large companies' subgroup exhibits the same pattern as the sample as a whole, the coefficient on BETA in the small companies' subgroup - although positive - is not statistically reliable. This might be due to deficiencies in the beta measure itself (e.g. non-trading bias) or the structure of the capital market in Switzerland (e.g. extreme concentration). Additional concerns could stem from the

14 For similar results for the Swiss market even in terms of magnitude see Raffournier (1995), who additionally included ownership structure, internationality and industry type in his analysis.

I5 However, to check for consistency, I also estimate the complete model using unlevered betas. This adjustment does not materially affect the results. 
measurement process of the cost of capital proxy. Using alternate estimation methods Botosan (1997) and Botosan and Plumlee (2000) each document a significant association between beta and cost of capital in the predicted direction. To the contrary, Gebhardt et al. (2000), on whose estimation technique I rely, were not able to find a positive relationship between the two variables in question. Finally, the theoretical framework of the CAPM indicates that market beta might be poorly suited for testing the influence of disclosure quality on cost of capital. The CAPM provides no role for risk factors other than market beta, e.g. estimation risk, to cause variation in cost of capital unless one assumes these factors are directly linked to market beta itself. Nevertheless, it should be noted that beyond the univariate analysis, market beta shows the expected behavior, especially when considering the results presented below (including a firm's reporting strategy).

The other two variables, market leverage and size, behave as predicted and the coefficients on LEV and MARKET are highly significant. ROE can be shown to be an increasing function of the amount of debt in a firm's capital structure and a decreasing function of its market value. Overall, the results support the validity of my measure of ex ante cost of capital. As can be seen from panel $B$, however, the maximum adjusted $R^{2}$ of $27.3 \%$ leaves substantial variation in ROE unexplained. I now turn to disclosure quality as another possibly omitted explanatory variable.

\section{Empirical Analysis of the Main Hypothesis}

Table 5 provides Pearson correlation coefficients between cost of equity capital and various firm characteristics including DRANK, the fractional rank of disclosure score. Except for BETA every coefficient has the expected sign and is highly significant. The correlation between ROE and DRANK is -0.478 and relevant at virtually all levels of statistical significance using a two-tail test. This result is consistent with my claim that the ex ante cost of equity capital decreases in disclosure quality, at least in an univariate setting. In the meantime ROE also exhibits a negative correlation with BETA (albeit not significant), MARKET and ANALYST as well as a positive correlation with LEV. The significant and positive correlation coefficient of 0.558 between market size and market beta supports my conjecture that there might exist a non-trading bias for small companies. To prevent multi-collinearity (correlation of 0.796 between analyst following and firm size) the MARKET and ANALYST variables are not included simultaneously in the multivariate analyses.

The main hypothesis is tested by regressing cost of equity capital on risk, disclosure level and size. This leads to the following regression model:

$$
\text { Cost of capital }{ }_{i}=\alpha+\beta_{1+2} \text { Risk }_{i}+\beta_{3} \text { Disclosure quality }_{i}+\beta_{4} \text { Size }_{i}+\varepsilon_{i}
$$

or more specifically:

$$
R O E_{i}=\alpha+\beta_{1} B E T A_{i}+\beta_{2} L E V_{i}+\beta_{3} D R A N K_{i}+\beta_{4} \ln \left(M A R K E T_{i}\right)+\varepsilon_{i}
$$

BETA and LEV are included in the analysis to account for a company's systematic and financial risk. MARKET is included to account for the richness of a firm's information environment as well as the significant association between cost of capital and market value presented earlier. The results obtained from estimating regression equation (7) using simple OLS 
are provided in table 6 panels A and B. Testing for the presence of heteroscedasticity does not indicate any problems (White, 1980), and, using Cook's distance, no influential data points have been detected.

All the coefficients behave as predicted and - with one exception - are significant at the $6 \%$ level or better. BETA and LEV show the expected positive relationship with ROE suggesting that cost of capital is related to systematic and financial risk in the Swiss market. Introducing unlevered betas into the complete model even improves the statistical power of the relationship (e.g. p-value for BETA 0.045), but does not affect the overall conclusions. MARKET is negatively related to cost of capital although not always significant suggesting that firm size might also serve as a proxy for several other, not closely defined influences. Finally, the fractional rank of disclosure quality as measured by DRANK (rank divided by number of firms) exhibits a negative association with ROE. The coefficients are highly significant regardless of the regression model specification. The results imply that cost of equity capital decreases with disclosure level even after controlling for cross-sectional variation in market beta, financial leverage and firm size. The magnitude of the coefficients on DRANK ranges from -0.0182 including BETA and MARKET to -0.0244 in the simple regression presented in panel A. This suggests that the companies in the sample with the most forthcoming corporate financial reporting (e.g. fractional rank equals one) enjoy somewhere between a $1.8 \%$ and $2.4 \%$ reduction in their cost of equity capital compared to the least forthcoming firms (e.g. fractional rank equals nearly zero). Alternatively stated, estimating the model with the absolute disclosure score instead of the fractional rank indicates that a one-unit increase in DISC is related to a reduction in cost of equity capital of about $0.1 \%$, holding all else equal. For example, Ciba SC, a Swiss chemical producer, could have possibly gained a $1 \%$ equity cost advantage over Rieter Holding, an engineering and machinery supplier, by providing more background, non-financial and value-based information, which constitutes a ten-point difference in respective disclosure scores. The results on disclosure quality though are not only statistically significant but also economically relevant.

However, the findings should be interpreted with caution. The standard error associated with the slope coefficients on DRANK is about $0.58 \%$, indicating that the "true" coefficient may fall somewhere in between 0.7 and $3.2 \%$ ( $95 \%$ confidence interval depending on the model specification). Furthermore, including disclosure level in the model increases the adjusted $\mathrm{R}^{2}$ to a maximum value of $38.1 \%$, but still leaves a substantial portion of ROE to be explained otherwise. And finally, if self-selection of disclosure policy is an issue, simple OLS will overestimate the effect of reporting quality on a firm's cost of equity capital.

\section{Specification Tests}

To assess the sensitivity of the above results I estimate several variations of the regression model: (1) since the forecast horizon is fixed and might be either too short or too long depending on a firm's position in its life cycle, I use different time horizons $(T=9$ or 15$)$ in estimating cost of equity capital; (2) I replace the fractional rank of the disclosure score by the absolute disclosure value; (3) market value of outstanding equity, my proxy for size, is substituted by the number of analysts following a specific firm; (4) in accordance with Lang and 
Lundholm (1993) I also estimate rank regressions to abstract from the precise functional form of the relation between ROE and the independent variables. None of the conclusions drawn from the previously reported results are changed. Specifically, the coefficients on DRANK (DISC) remain negative at the $1 \%$ level of statistical significance or better (one-tail test). In some cases, however, the coefficient on MARKET loses its predictive power, especially when the explicit forecast period is expanded as far as 15 years or when rank-transformed data is used.

Following Botosan (1997) I also test for differences in cost of equity capital contingent on a firm's analyst following adopting the model specification given below:

$$
\begin{aligned}
R O E_{i}= & \alpha_{0}+\alpha_{1} D U_{i}+\beta_{1} B E T A_{i}+\beta_{2} L E V_{i}+\beta_{3} D R A N K_{i}+\beta_{4} D R A N K_{i} * D U_{i} \\
& +\beta_{5} \ln \left(M A R K E T_{i}\right)+\varepsilon_{i}
\end{aligned}
$$

DU is a categorical variable set equal to one if the number of analysts is less than or equal to the median and zero otherwise. I let the dummy enter the model on its own and in interaction with DRANK, which allows the slope coefficient associated with disclosure quality and the intercept to vary for low versus high analyst attention. As the coefficient on the interaction term DRANK *DU is negative $(-0.0020)$ but far from statistically significant and all the other variables behave as predicted (e.g. coefficient on DRANK -0.0195 with a p-value of 0.017 ), I do not find any evidence of a differing association between cost of equity capital and disclosure quality for narrowly followed firms. ${ }^{16}$

As argued above, the OLS estimate of the disclosure level coefficient might suffer from self-selection bias. Accordingly, a system of two equations in which both cost of equity capital and disclosure level appear as endogenous is estimated utilizing 2SLS. In the presence of endogeneity this procedure will yield estimators that are consistent and efficient. In the first equation, a firm's reporting decision is analyzed using the following disclosure model:

$$
\begin{aligned}
\text { Disclosure quality }_{i}= & \omega+\delta_{1} \text { Size }_{i}+\delta_{2} \text { Profitability level }_{i}+\delta_{3}{\text { Stock listing } \text { status }_{i}} \\
& +\delta_{4} \text { Financial leverage }_{i}+\delta_{5} \text { Audit firm size }_{i}+\gamma_{i}
\end{aligned}
$$

or more specifically:

$$
D R A N K_{i}=\omega+\delta_{1} \ln \left(M A R K E T_{i}\right)+\delta_{2} R E T U R N_{i}+\delta_{3} L I S T_{i}+\delta_{4} L E V_{i}+\delta_{5} A U D I T_{i}+\gamma_{i}
$$

where all the variables are as previously described. The explanative power of the regression (not reported) amounts to $34.2 \%$ (adjusted $\mathrm{R}^{2}$ ) and, consistent with prior literature, all the coefficients are positive and significant at the $8 \%$ level or better.

Table 6 panel C presents results from estimating equation (7) - the cost of capital model taking into account that disclosure level is now represented by a linear combination of the

16. In another analysis not reported the sample is subdivided according to analyst following (number of analysts $\leq$ median versus number of analysts $>$ median), accounting standard (I $\Lambda$ S/US G $\Lambda \wedge P$ adopters versus nonadopters), and membership of the Swiss Market Index SMI (member firms versus non-members). The SMI consists of the 20 to 25 largest Swiss companies according to their market capitalization. Subsequently, separate regressions are estimated for each subsample. The coefficient on DR $\Lambda$ NK is always negative and with the exception of non-I $\Lambda$ S/US G $\Lambda \Lambda$ P-adopters $(n=23)$ and SMI firms $(n=14)$ highly significant. 
predetermined variables in the system. The original DRANK variable is thus replaced by the fitted values from the first-stage regression. The fitted values serve as proxy for disclosure quality but at the same time exhibit less correlation with the disturbance term. By this substitution 2SLS should produce an unbiased estimate of the relation between a firm's voluntary reporting choice and its cost of capital. While BETA and LEV significantly confirm the expected positive association with ROE, the results on DRANK and MARKET are mixed. Whereas the size variable - except for one case - loses its statistical power, disclosure quality behaves as predicted. In two out of three cases the coefficients are reliable at conventional levels of statistical significance. The results are even more convincing when using unadjusted p-values for DRANK (e.g. $0.259,0.044$ and 0.033 , respectively) instead of p-values that are based on White's corrected standard errors to prevent heteroscedasticity. Moreover, as the significant coefficients become more negative when using 2SLS, the OLS approach actually understates, not overestimates the marginal effect of disclosure quality. The findings, however, are subject to several methodological concerns: as the $\mathrm{R}^{2}$ values in the first-stage regressions - although comparable to other studies in the literature - are rather low for predictive purposes, the original explanatory variable is not well represented by the instruments. Furthermore, the results obtained by applying 2SLS to small samples and the inferences drawn from them should be interpreted with caution, as this statistical technique is of the largesample type. Nonetheless, the attempt to explicitly address self-selection bias generally supports the main hypothesis outlined above.

\section{Summary and Conclusions}

The relationship between disclosure quality and cost of equity capital is an important topic in theory and practice and generally, a negative association is assumed. Theoretical research supports this claim by emphasizing the effect of greater disclosure on stock market liquidity and estimation risk. On the other hand, anecdotal evidence indicates that companies continuously try to reduce their equity financing costs, thereby increasing shareholder value through enhanced corporate financial reporting. However, empirical evidence on this relation is rather weak for two main reasons: (1) disclosure quality as well as cost of equity capital is subjective in nature and very difficult to assess, and (2) most prior studies focus on publicly held companies in the US that operate in an already rich disclosure environment, making it hard to document the conjectured relation empirically.

In this paper I provide further evidence on the nature of the above relationship and try to quantify the effect of a firm's voluntary disclosure policy on its cost of capital in a Swiss environment. Switzerland seems especially suited for an analysis of this kind given that Swiss firms have considerable reporting discretion and the mandated level of disclosure is low. For a cross-sectional sample of 73 non-financial companies I show a negative and highly significant association between ROE, my measure of cost of equity capital, and DRANK, the fractional rank of my disclosure score. The magnitude is such that the most forthcoming firms enjoy about a $1.8 \%$ to $2.4 \%$ cost advantage over the least forthcoming firms. The conclusions hold even after taking into account systematic risk, financial risk and firm size. Controlling for self-selection - a major concern in disclosure studies - the results are generally (but not 
exclusively) consistent with the main hypothesis although at lower levels of statistical significance. One reason for the strong relationship might be found in differing institutional factors between US and Swiss capital markets. In line with Botosan (1997) or Leuz and Verrecchia (2000), the findings support the view that the economic consequences of an increased reporting strategy should be easier to detect when the disclosure environment is low.

The conclusions, however, should be interpreted with due caution: as the study is limited to a relatively small sample in a single market during a one-year period, it may prove difficult to generalize the results to other markets and time horizons. To further diminish potential distortions from endogeneity, future work should concentrate on a better understanding of a firm's voluntary reporting behavior. Useful insights can also be expected from studying the change in disclosure level over time and its implications for a firm's risk position. Finally, from a more international perspective, similar techniques could be adopted to address differences in disclosure quality in response to different legislation and in different countries thereby investigating institutional factors influencing a particular corporate reporting environment.

\section{References}

Ahmed, K. and Courtis, J. (1999) 'Associations between corporate characteristics and disclosure levels in annual reports: A meta-analysis', British Accounting Review, 31(1): 35-61.

Amihud, Y. and Mendelson, H. (1986) 'Asset pricing and the bid-ask spread', Journal of Financial Economics, 17(2): 223-249.

Auer, K. (1998) 'Der Einfluss des Wechsels vom Rechnungslegungsstandard auf die Risikoparameter von schweizerischen Aktien', Zeitschrift für betriebswirtschaftliche Forschung, 50(2): 129-155.

Baiman, S. and Verrecchia, R. (1996) 'The relation among capital markets, financial disclosure, production efficiency, and insider trading', Journal of Accounting Research, 34(1): $1-22$.

Bernard, V. (1994) 'Accounting-based valuation methods, determinants of market-to-book ratios, and implications for financial statements analysis', Working paper, University of Michigan.

Bernard, V. (1995) 'The Feltham-Ohlson framework: Implications for empiricists', Contemporary Accounting Research, 11(2): 733-747.

Bloomfield, R. and Wilks, T. (2000) 'Disclosure effects in the laboratory: Liquidity, depth, and the cost of capital', The Accounting Review, 75(1): 13-41.

Blume, M. (1975) 'Betas and their regression tendencies', Journal of Finance, 30(3): 785 795.

Botosan, C. (1997) 'Disclosure level and the cost of equity capital', The Accounting Review, $72(3): 323-349$. 
Botosan, C. and Plumlee, M. (2000) 'Disclosure level and expected cost of equity capital: An examination of analysts' rankings of corporate disclosure and alternative methods of estimating expected cost of equity capital', Working paper, University of Utah.

Brown, L. and Rozeff, M. (1978) 'The superiority of analyst forecasts as measures of expectations: evidence from earnings', Journal of Finance, 33(1): 1-16.

Caramanolis, B., Gardiol, L., Gibson, R. and Tuchschmid, N. (1999) 'Are investors sensitive to the quality and the disclosure of financial statements?', European Finance Review, 3(2): 131-159.

Clarkson, P., Guedes, J. and Thompson, R. (1996) 'On the diversification, observability, and measurement of estimation risk', Journal of Financial and Quantitative Analysis, 31(1): 69-84.

Claus, J. and Thomas, J. (1999) 'The equity risk premium is much lower than you think it is: empirical estimates from a new approach', Working paper, Columbia University.

Clement, M., Frankel, R. and Miller, J. (2000) 'The effect of confirming management earnings forecasts on cost of capital', Working paper, University of Texas at Austin and University of Michigan.

Coles, J., Loewenstein, U. and Suay, J. (1995) 'On equilibrium pricing under parameter uncertainty', Journal of Financial and Quantitative Analysis, 30(3): 347-364.

Darrough, M. and Stoughton, N. (1990) 'Financial disclosure policy in an entry game', Journal of Accounting \& Economics, 12(1-3): 219-243.

Dechow, P., Hutton, A. and Sloan, R. (1999) 'An empirical assessment of the residual income valuation model', Journal of Accounting \& Economics, 26(1-3): 1-34.

Diamond, D. and Verrecchia, R. (1991) 'Disclosure, liquidity, and the cost of capital', Journal of Finance, 46(4): 1325-1359.

Edwards, E. and Bell, P. (1961) The theory and measurement of business income. Berkeley: University of California Press.

Feltham, G. and Ohlson, J. (1995) 'Valuation and clean surplus accounting for operating and financial activities', Contemporary Accounting Research, 11(2): 689-731.

Fried, D. and Givoly, D. (1982) 'Financial analysts' forecasts of earnings: A better surrogate for market expectations', Journal of Accounting \& Economics, 4(2): 85-107.

Gebhardt, W., Lee, C. and Swaminathan, B. (2000) 'Toward an implied cost-of-capital', Working paper, Cornell University.

Glosten, L. and Milgrom, P. (1985) 'Bid, ask and transaction prices in a specialist market with heterogeneously informed traders', Journal of Financial Economics, 14(1): 71-100.

Handa, P. and Linn, S. (1993) 'Arbitrage pricing with estimation risk', Journal of Financial and Quantitative Analysis, 28(1): 81-100. 
Harris, M. and Muller, K. (1999) 'The market valuation of IAS versus US-GAAP accounting measures using Form 20-F reconciliations', Journal of Accounting \& Economics, 26(1-3): $285-312$.

Healy, P., Hutton, A. and Palepu, K. (1999) 'Stock performance and intermediation changes surrounding sustained increases in disclosure', Contemporary Accounting Research, 16(3): 485-520.

Klein, R. and Bawa, V. (1976) 'The effect of estimation risk on optimal portfolio choice', Journal of Financial Economics, 3(3): 215-231.

Lang, M. and Lundholm, R. (1993) 'Cross-sectional determinants of analyst ratings of corporate disclosures', Journal of Accounting Research, 31(2): 246-271.

Lee, C., Myers, J. and Swaminathan, B. (1999) 'What is the intrinsic value of the Dow?', Journal of Finance, 54(5): 1693-1741.

Leuz, C. and Verrecchia, R. (2000) 'The economic consequences of increased disclosure', Journal of Accounting Research, 38(Supplement): 91-124.

Lücke, W. (1955) 'Investitionsrechnungen auf der Grundlage von Ausgaben oder Kosten?', Zeitschrift für handelswissenschaftliche Forschung, 7: 310-324.

Marquardt, C. and Wiedman, C. (1998) 'Voluntary disclosure, information asymmetry, and insider selling through secondary equity offerings', Contemporary Accounting Research, 15(4): 505-537.

Modigliani, F. and Miller, M. (1958) 'The cost of capital, corporation finance and the theory of investment', The American Economic Review, 48(3): 261-297.

Myers, J. (1999) 'Implementing residual income valuation with linear information dynamics', The Accounting Review, 74(1): 1-28.

O'Brien, P. (1988) 'Analysts' forecasts as earnings expectations', Journal of Accounting \& Economics, 10(1): 53-83.

Ohlson, J. (1995) 'Earnings, book values, and dividends in equity valuation', Contemporary Accounting Research, 11(2): 661-687.

Peasnell, K. (1982) 'Some formal connections between economic values and yields and accounting numbers', Journal of Business Finance \& Accounting, 9(3): 361-381.

Penman, S. (1997) 'A synthesis of equity valuation techniques and the terminal value calculation for the dividend discount model', Review of Accounting Studies, 2(4): 303-323.

Penman, S. and Sougiannis, T. (1998) 'A comparison of dividend, cash flow, and earnings approaches to equity valuation', Contemporary Accounting Research, 15(3): 343-383.

Preinreich, G. (1938) 'Annual survey of economic theory: The theory of depreciation', Econometrica, 6(3): 219-241.

Raffournier, B. (1995) 'The determinants of voluntary financial disclosure by Swiss listed companies', European Accounting Review, 4(2): 261-280. 
Schultz, J. and Zimmermann, H. (1989) 'Risikoanalyse schweizerischer Aktien: Stabilität und Prognose von Betas', Finanzmarkt und Portfolio Management, 3(3): 196-209.

Sengupta, P. (1998) 'Corporate disclosure quality and the cost of debt', The Accounting Review, 73(4): 459-474.

Verrecchia, R. (1983) 'Discretionary disclosure', Journal of Accounting \& Economics, 5(3): 179-194.

Verrecchia, R. (1990) 'Information quality and discretionary disclosure', Journal of Accounting \& Economics, 12(4): 365-380.

Verrecchia, R. (1999) 'Disclosure and the cost of capital: A discussion', Journal of Accounting \& Economics, 26(1-3): 271-283.

Wagenhofer, A. (1990) 'Voluntary disclosure with a strategic opponent', Journal of Accounting \& Economics, 12(4): 341-363.

Watts, R. and Zimmerman, J. (1986) Positive accounting theory. Englewood Cliffs, N. J.: Prentice-Hall.

Welker, M. (1995) 'Disclosure policy, information asymmetry, and liquidity in equity markets', Contemporary Accounting Research, 11(2): 801-827.

White, H. (1980) 'A heteroskedasticity-consistent covariance matrix estimator and a direct test for heteroskedasticity', Econometrica, 48(4): 817-838. 
TABLE 1

Summary of Sample Selection Process

\begin{tabular}{|c|c|c|c|}
\hline & \multicolumn{2}{|c|}{ Number } & Percent \\
\hline Firms with disclosure score DISC available & & 111 & $100 \%$ \\
\hline Firms not publicly traded on the Swiss Exchange SWX & -8 & & \\
\hline $\begin{array}{l}\text { Firms not followed by } \mathrm{I} / \mathrm{B} / \mathrm{E} / \mathrm{S} \text { International (no financial } \\
\text { analysts' forecast data available) }\end{array}$ & -8 & & \\
\hline $\begin{array}{l}\text { Firms with fiscal year end not on December } 31,1997 \text {, or } \\
\text { not within the first quarter of } 1998\end{array}$ & -4 & -20 & $-18 \%$ \\
\hline Firms available for analysis & & 91 & $82 \%$ \\
\hline Financial institutions (banking and insurance companies) & & -18 & $-16 \%$ \\
\hline Total number of sample firms & & 73 & $66 \%$ \\
\hline
\end{tabular}

Notes: DISC is the overall company disclosure score for fiscal 1997 provided by the Swiss Banking Institute at the University of Zurich. 
TABLE 2

\section{Descriptive Statistics for Sample Firms}

\begin{tabular}{|c|c|c|c|c|c|c|c|c|}
\hline \multirow[b]{2}{*}{ Variable } & \multirow[b]{2}{*}{$n$} & \multirow[b]{2}{*}{ Mean } & \multirow[b]{2}{*}{ Min. } & \multicolumn{3}{|c|}{ Percentile } & \multirow[b]{2}{*}{ Max. } & \multirow{2}{*}{$\begin{array}{l}\text { Standard } \\
\text { Deviation }\end{array}$} \\
\hline & & & & $Q 1$ & $Q 2$ & $Q 3$ & & \\
\hline \multicolumn{9}{|l|}{ Size: } \\
\hline MARKET & 73 & 6292 & 27 & 225 & 661 & $2^{\prime} 067$ & $151 ' 806$ & $23 ' 198$ \\
\hline ASSET & 73 & $4^{\prime} 641$ & 55 & 379 & 1'221 & $2^{\prime} 645$ & $54^{\prime} 776$ & $10^{\prime} 934$ \\
\hline SALES & 71 & $4^{\prime} 167$ & 84 & 450 & l'073 & $3 ' 271$ & $69^{\prime} 998$ & $9^{\prime} 557$ \\
\hline NEMP & 69 & $166^{\prime} 159$ & 247 & 1'423 & $4^{\prime} 120$ & $12^{\prime} 437$ & $225^{\prime} 808$ & $38^{\prime} 443$ \\
\hline \multicolumn{9}{|l|}{ Risk: } \\
\hline BETA & 73 & 0.63 & -0.15 & 0.42 & 0.61 & 0.86 & 1.37 & 0.33 \\
\hline LEV & 73 & 0.84 & 0.00 & 0.11 & 0.35 & 0.76 & 11.99 & 1.77 \\
\hline \multicolumn{9}{|l|}{ Disclosure: } \\
\hline ANALYST & 73 & 11.2 & 1 & 7 & 11 & 15 & 26 & 6.2 \\
\hline DISC & 73 & 18.3 & 7 & 14 & 18 & 22 & 30 & 5.6 \\
\hline \multicolumn{9}{|c|}{ Ex ante cost of capital: } \\
\hline ROE & 73 & $6.18 \%$ & $2.82 \%$ & $5.04 \%$ & $6.06 \%$ & $7.03 \%$ & $10.29 \%$ & $1.49 \%$ \\
\hline
\end{tabular}

Notes: MARKET is the market value of outstanding equity at the beginning of 1998 in CHF millions. $\Lambda$ SSET is the book value of total assets, S $\Lambda$ LES is total sales, both for fiscal 1997 in CHF millions. NEMP is the number of employees reported for fiscal 1997. BET $\Lambda$ is estimated via a market model regression requiring at least 24 weekly return observations in the two-year period ended June 30,1998. LEV is the ratio of total debt to market value of outstanding equity at the beginning of 1998. AN NLYST is the number of analysts following a specific firm as of June 1998 , reported by $\mathrm{I} / \mathrm{B} / \mathrm{E} / \mathrm{S}$ International. DISC is the overall company disclosure score for fiscal 1997 provided by the Swiss Banking Institute at the University of Zurich. ROE is my estimate of future expected cost of equity capital derived as the internal rate of return from a twelve-year version of the residual income model as described in the text. The sample consists of 73 non-financial companies listed on the Swiss Exchange SWX, where the necessary forecast and disclosure data is available. 
TABLE 3

Pearson Correlation Coefficients for Disclosure Scores and Firm Characteristics

\begin{tabular}{|c|c|c|c|c|c|c|c|c|c|}
\hline Variable & DISC & DISC_I & DISC_2 & DISC_3 & ANALYST & MARKET & RETURN & LIST & $L E V$ \\
\hline \multirow[t]{2}{*}{$\overline{\text { DISC_1 }_{1}}$} & 0.719 & & & & & & & & \\
\hline & $(0.000)$ & & & & & & & & \\
\hline \multirow[t]{2}{*}{ DISC_2 } & 0.826 & 0.316 & & & & & & & \\
\hline & $(0.000)$ & $(0.006)$ & & & & & & & \\
\hline \multirow[t]{2}{*}{ DISC_ 3} & 0.625 & 0.223 & 0.365 & & & & & & \\
\hline & $(0.000)$ & $(0.058)$ & $(0.001)$ & & & & & & \\
\hline \multirow[t]{2}{*}{ ANALYST } & 0.563 & 0.265 & 0.414 & 0.651 & & & & & \\
\hline & $(0.000)$ & $(0.023)$ & $(0.000)$ & $(0.000)$ & & & & & \\
\hline \multirow[t]{2}{*}{ MARKET } & 0.557 & 0.199 & 0.453 & 0.665 & 0.796 & & & & \\
\hline & $(0.000)$ & $(0.091)$ & $(0.000)$ & $(0.000)$ & $(0.000)$ & & & & \\
\hline \multirow[t]{2}{*}{ RETURN } & 0.206 & 0.129 & 0.235 & 0.041 & 0.022 & 0.166 & & & \\
\hline & $(0.081)$ & $(0.276)$ & $(0.046)$ & $(0.733)$ & $(0.855)$ & $(0.160)$ & & & \\
\hline \multirow[t]{2}{*}{ LIST } & 0.431 & 0.305 & 0.301 & 0.377 & 0.564 & 0.583 & -0.035 & & \\
\hline & $(0.000)$ & $(0.009)$ & $(0.010)$ & $(0.001)$ & $(0.000)$ & $(0.000)$ & $(0.768)$ & & \\
\hline \multirow[t]{2}{*}{ LEV } & 0.053 & 0.053 & 0.102 & -0.095 & -0.097 & -0.302 & -0.172 & -0.149 & \\
\hline & $(0.658)$ & $(0.656)$ & $(0.389)$ & $(0.426)$ & $(0.417)$ & $(0.009)$ & $(0.146)$ & $(0.209)$ & \\
\hline \multirow[t]{2}{*}{ AUDIT } & 0.273 & 0.230 & 0.217 & 0.136 & 0.156 & 0.182 & -0.020 & 0.108 & 0.054 \\
\hline & $(0.019)$ & $(0.050)$ & $(0.065)$ & $(0.250)$ & $(0.186)$ & $(0.123)$ & $(0.869)$ & $(0.362)$ & $(0.647)$ \\
\hline
\end{tabular}

Notes: The p-values quoted above (in parentheses) are for a two-tail test of statistical significance. The natural log of market value is included in the analysis. DISC is the overall company disclosure score, DISC_ 1 is the partial company disclosure score for background and non-financial information, DISC 2 for trend analysis and management discussion and analysis, DISC 3 for risk, value-based and projected information. Disclosure scores are obtained from annual reports for the fisscal year 1997 and provided by the Swiss Banking Institute at the University of Zurich. ANALYST is the number of analysts following a specific firm as of June 1998 , reported by I/B/E/S International. MARKET is the market value of outstanding equity at the beginning of 1998 in CHF millions. RETURN equals the average realized return on equity for sample firms over the last five years. LIST is a categorical variable set equal to one if the firm's shares are multiple listed and zero otherwise. LEV is the ratio of total debt to market value of outstanding equity at the beginning of 1998. AUDIT is a categorical variable set equal to one if the firm is audited by a "Big Six" audit firm and zero otherwise. All calculations are based on 73 observations. 
TABI,F 4

Regression of Ex ante Cost of Capital on Beta, Leverage and Market Value

\begin{tabular}{|c|c|c|c|c|c|}
\hline & Intercept & $\begin{array}{c}B E T A \\
(+)\end{array}$ & $\begin{array}{c}L E V \\
(+)\end{array}$ & $\begin{array}{c}M A R K E T \\
\text { (-) }\end{array}$ & Adj. $R^{2}$ \\
\hline \multicolumn{6}{|c|}{ Panel A: Simple Regressions (OLS) } \\
\hline Coefficient & 0.0647 & -0.0047 & & & $0.0 \%$ \\
\hline P-value & $(0.000)$ & $(0.805)$ & & & $(0.390)$ \\
\hline Coefficient & 0.0564 & & 0.0089 & & $17.7 \%$ \\
\hline P-value & $(0.000)$ & & $(0.000)$ & & $(0.000)$ \\
\hline Coefficient & 0.0891 & & & -0.0041 & $21.4 \%$ \\
\hline P-value & $(0.000)$ & & & $(0.000)$ & $(0.000)$ \\
\hline \multicolumn{6}{|c|}{ Panel B: Multiple Regressions (OLS) } \\
\hline Coefficient & 0.0899 & 0.0108 & & -0.0052 & $24.2 \%$ \\
\hline P-value & $(0.000)$ & $(0.031)$ & & $(0.000)$ & $(0.000)$ \\
\hline Coefficient & 0.0786 & & 0.0058 & -0.0030 & $26.9 \%$ \\
\hline P-value & $(0.000)$ & & $(0.007)$ & $(0.001)$ & $(0.000)$ \\
\hline Coefficient & 0.0808 & 0.0070 & 0.0049 & -0.0040 & $27.3 \%$ \\
\hline P-value & $(0.000)$ & $(0.118)$ & $(0.025)$ & $(0.001)$ & $(0.000)$ \\
\hline
\end{tabular}

Notes: The p-values quoted above (in parentheses) are for a one-tail test of statistical significance for directional predictions and for a two-tail test otherwise. The natural log of market value is included in the analysis. Data for financial leverage is winsorized at the upper and lower $5 \%$ of observations. White's (1980) test does not indicate the presence of heteroscedasticity. Using Cook's distance, no influential data points were detected. ROE is my estimate of future expected cost of equity capital derived as the internal rate of return from a twelve-year version of the residual income model as described in the text. BET $\Lambda$ is estimated via a market model regression requiring at least 24 weekly return observations in the two-year period ended June 30,1998 . LEV is the ratio of total debt to market value of outstanding equity at the beginning of 1998. MARKET is the market value of outstanding equity at the beginning of 1998 in CHF millions. The sample consists of 73 non-financial companies listed on the Swiss Exchange SWX, where the necessary forecast and disclosure data is available. 
TABLE 5

\section{Pearson Correlation Coefficients for Ex ante Cost of Capital} and Firm Characteristics

\begin{tabular}{lccccc} 
Variable & ROE & BETA & LEV & DRANK & MARKET \\
\hline BETA & -0.102 & & & & \\
& $(0.390)$ & & & & \\
LEV & 0.251 & -0.041 & & & \\
& $(0.032)$ & $(0.733)$ & & & \\
DRANK & -0.478 & 0.407 & 0.066 & & \\
& $(0.000)$ & $(0.000)$ & $(0.580)$ & & \\
MARKET & -0.474 & 0.558 & -0.302 & 0.542 & \\
& $(0.000)$ & $(0.000)$ & $(0.009)$ & $(0.000)$ & 0.796 \\
ANALYST & -0.372 & 0.701 & -0.097 & 0.545 & $(0.000)$ \\
\hline
\end{tabular}

Notes: The p-values quoted above (in parentheses) are for a two-tail test of statistical significance. The natural $\log$ of market value is included in the analysis. ROE is my estimate of future expected cost of equity capital derived as the internal rate of return from a twelve-year version of the residual income model as described in the text. BET $\Lambda$ is estimated via a market model regression requiring at least 24 weekly return observations in the two-year period ended June 30,1998 . LEV is the ratio of total debt to market value of outstanding equity at the beginning of 1998 . DR $\Lambda$ NK is the fractional rank (rank divided by number of firms) of the firm's disclosure score. MARKET is the market value of outstanding equity at the beginning of 1998 in CHF millions. ANALYST is the number of analysts following a specific firm as of June 1998, reported by $\mathrm{I} / \mathrm{B} / \mathrm{E} / \mathrm{S}$ International. $\mathrm{All}$ calculations are based on 73 observations. 
TABI.F 6

\section{Regression of Ex ante Cost of Capital on Beta, Leverage, Disclosure Score and Market Value}

$$
\mathrm{ROE}_{\mathrm{i}}=\alpha+\beta_{1} \mathrm{BETA}_{\mathrm{i}}+\beta_{2} \mathrm{LEV}_{\mathrm{i}}+\beta_{3} \mathrm{DRANK}_{\mathrm{i}}+\beta_{4} \ln \left(\mathrm{MARKET}_{\mathrm{i}}\right)+\varepsilon_{\mathrm{i}}
$$

Intercept BETA LEV DRANK MARKET

Adj. $R^{2}$

\begin{tabular}{|c|c|c|c|c|c|c|}
\hline \multirow{2}{*}{\multicolumn{7}{|c|}{$\frac{(+)}{\text { Panel A: Simple Regression (OLS) }}$}} \\
\hline & & & & & & \\
\hline Coefficient & 0.0736 & & & -0.0244 & & $21.8 \%$ \\
\hline P-value & $(0.000)$ & & & $(0.000)$ & & $(0.000)$ \\
\hline \multicolumn{7}{|c|}{ Panel B: Multiple Regressions (OLS) } \\
\hline Coefficient & 0.0877 & 0.0133 & & -0.0182 & -0.0038 & $32.2 \%$ \\
\hline P-value & $(0.000)$ & $(0.009)$ & & $(0.002)$ & $(0.001)$ & $(0.000)$ \\
\hline Coefficient & 0.0732 & & 0.0073 & -0.0200 & -0.0009 & $36.6 \%$ \\
\hline P-value & $(0.000)$ & & $(0.001)$ & $(0.001)$ & $(0.198)$ & $(0.000)$ \\
\hline Coefficient & 0.0758 & 0.0088 & 0.0062 & -0.0208 & -0.0020 & $38.1 \%$ \\
\hline P-value & $(0.000)$ & $(0.055)$ & $(0.004)$ & $(0.001)$ & $(0.060)$ & $(0.000)$ \\
\hline \multicolumn{7}{|c|}{ Panel C: Multiple Regressions (2SLS) } \\
\hline Coefficient & 0.0886 & 0.0123 & & -0.0113 & -0.0044 & $30.9 \%$ \\
\hline P-value & $(0.000)$ & $(0.021)$ & & $(0.302)$ & $(0.016)$ & $(0.000)$ \\
\hline Coefficient & 0.0695 & & 0.0084 & -0.0338 & 0.0005 & $31.5 \%$ \\
\hline P-value & $(0.000)$ & & $(0.001)$ & $(0.062)$ & $(0.578)$ & $(0.000)$ \\
\hline Coefficient & 0.0718 & 0.0102 & 0.0073 & -0.0374 & -0.0004 & $30.6 \%$ \\
\hline P-value & $(0.000)$ & $(0.034)$ & $(0.003)$ & $(0.043)$ & $(0.437)$ & $(0.000)$ \\
\hline
\end{tabular}

Notes: The p-values quoted above (in parentheses) are for a one-tail test of statistical significance for directional predictions and for a two-tail test otherwise. The natural log of market value is included in the analysis. Data for financial leverage is winsorized at the upper and lower $5 \%$ of observations. In the OLS regressions, White's (1980) test does not indicate the presence of heteroscedasticity. In the 2SLS regressions, reported p-values are based on White's heteroscedasticity-consistent standard errors. Using Cook's distance, no influential data points were detected. ROE is my estimate of future expected cost of equity capital derived as the internal rate of return from a twelve-year version of the residual income model as described in the text. BET $\Lambda$ is estimated via a market model regression requiring at least 24 weekly return observations in the two-year period ended June 30,1998 . LEV is the ratio of total debt to market value of outstanding equity at the beginning of 1998 . DR $\Lambda \mathrm{NK}$ is the fractional rank (rank divided by number of firms) of the firm's disclosure score. MARKET is the market value of outstanding equity at the beginning of 1998 in CHF millions. The sample consists of 73 non-financial companies listed on the Swiss Exchange SWX, where the necessary forecast and disclosure data is available. 


\section{APPENDIX A}

\section{Summary of the Major Elements of Disclosure Score DISC}

Part I: Background and non-financial information (20 points)

1. Principle products

2. Principle markets and market shares

3. Business environment and critical factors of success

4. Corporate governance and organizational structure

5. Client satisfaction

6. Employee satisfaction

7. Investments in human resources and management development

8. Investments in research \& development and other intangible assets

9. Product life cycle and innovation

10. Operational efficiency

Part II: Trend analysis and management discussion and analysis (20 points)

1. Trend in sales over the last several years

2. Sales by region and/or business segment

3. Trend in operating income over the last several years

4. Operating income by region and/or business segment

5. Trend in capital expenditures over the last several years

6. Capital expenditures by region and/or business segment

7. Trend in stock prices and total shareholder return

8. Discussion of changes in sales and market share

9. Discussion of changes in operating income

10. Discussion of changes in capital expenditures or research \& development

Part III: Risk, value-based and projected information (14 points)

1. Use and implementation of risk management

2. Quantitative risk exposure

3. Use and implementation of value-based management

4. Quantitative measures for shareholder value creation

5. Management compensation

6. Profit forecasts

7. Sales and growth forecasts

Notes: The above is a list of items included in the disclosure score DISC which covers annual reports of 73 Swiss listed companies for fiscal 1997. Further information can be obtained from the Swiss Banking Institute at the University of Zurich. 


\section{APPENDIX B}

Calculation of Ex ante Cost of Capital for the Forbo Group

(in CHF per registered share unless otherwise stated)

\section{Parameters:}

Earnings forccasts

Book valuc

Dividend payout ratio

Actual price

Swiss market return on equity

\section{Ex ante cost of capital}

\begin{tabular}{|c|c|c|}
\hline FY1 & $\mathrm{FY} 2$ & $\mathrm{TG}$ \\
\hline 53.70 & 59.50 & $6.40 \%$ \\
\hline 480.38 & \multicolumn{2}{|l|}{ BOOK } \\
\hline $28 \%$ & \multicolumn{2}{|l|}{ PAYOUT } \\
\hline 847.95 & \multicolumn{2}{|l|}{ PRICE } \\
\hline $8.98 \%$ & \multicolumn{2}{|l|}{ ROE_SWISS } \\
\hline $6.72 \%$ & ROE & \\
\hline
\end{tabular}

Explicit forecast period

Year

Earnings

Dividend

\begin{tabular}{|c|c|c|}
\hline 1998 & 1999 & 2000 \\
\hline 53.70 & 59.50 & 63.31 \\
\hline
\end{tabular}

Book value (beginning of ycar)

Effective return on equity

Ex ante cost of capital

Abnormal return on equity

Residual income (RI)

Present valuc of RI

\begin{tabular}{|c|c|c|c|c|c|c|c|c|c|}
\hline \multicolumn{9}{|c|}{ Fading period ( 9 ycars) } & \multirow{2}{*}{$\underbrace{\text { Perpctuity }}_{\mathbf{R V}}$} \\
\hline 2001 & 2002 & 2003 & 2004 & 2005 & 2006 & 2007 & 2008 & 2009 & \\
\hline 66.89 & 70.51 & 74.16 & 77.82 & 81.48 & 85.10 & 88.68 & 92.18 & 95.58 & 95.58 \\
\hline 18.86 & 19.88 & 20.91 & 21.95 & 22.98 & 24.00 & 25.01 & 25.99 & 95.58 & 95.58 \\
\hline 607.11 & 655.14 & 705.76 & 759.01 & 814.88 & 873.38 & 934.49 & 998.16 & $1^{\prime} 064.34$ & $1^{\prime} 064.34$ \\
\hline $11.02 \%$ & $10.76 \%$ & $10.51 \%$ & $10.25 \%$ & $10.00 \%$ & $9.74 \%$ & $9.49 \%$ & $9.23 \%$ & $8.98 \%$ & $8.98 \%$ \\
\hline $6.72 \%$ & $6.72 \%$ & $6.72 \%$ & $6.72 \%$ & $6.72 \%$ & $6.72 \%$ & $6.72 \%$ & $6.72 \%$ & $6.72 \%$ & $6.72 \%$ \\
\hline $4.29 \%$ & $4.04 \%$ & $3.78 \%$ & $3.53 \%$ & $3.27 \%$ & $3.02 \%$ & $2.76 \%$ & $2.51 \%$ & $2.26 \%$ & $2.26 \%$ \\
\hline 26.06 & 26.45 & 26.70 & 26.78 & 26.68 & 26.37 & 25.83 & 25.05 & 24.00 & 356.91 \\
\hline 20.09 & 19.10 & 18.07 & 16.98 & 15.85 & 14.68 & 13.47 & 12.24 & 10.99 & 163.44 \\
\hline
\end{tabular}

Cum. present value of RI

16.78

17.85

$480.38 \quad 518.94 \quad 561.66$

$11.18 \% \quad 11.47 \% \quad 11.27 \%$

$6.72 \%-6.72 \%$

$4.45 \% \quad 4.74 \%$

$6.72 \%$

$21.39 \quad 24.60 \quad 25.54$

21.60

21.01

367.57

Implicd valuc

847.95

Notes: This appendix provides an example of the ex ante cost of capital calculation for the Forbo (jroup as of June 30, 1998. The following parancters are used: FYI and FY2 are analysts' consensus forceasts for one-ycarwhead and two-ycar-ahead camings per share as of June 1998. LTOj is the incan future expected long-tern carnings growth rate as of June 1998. Analyst data is provided by I/B/E/S International. BOOK is the book valuc per share at the beginning of fiseal 1998. PAYOUT cquals the company's average dividend payout ratio over the last five years. PRICE is the equally weighted stoek price for the inonth of June I998. ROE SWISS is the inedian valuc of past retums on equity from all Swiss listed companics over the last five years. ROE is ny cstinate of future cxpected cost of cquity eapital derived as the internal rate of retum from a twelve-ycar version of the residual incoinc inodel. A four-stage approach is adopted to computc this rate: first, I use analysts' carnings forecasts and long-tern growth rate as carnings proxy for the next threc ycars, sceond, I derive future cxpeced camings by lincarly fading year 2000 return on cquity (II.27\%) to the historical Swiss inarket median ( $8.98 \%)$ by the ycar 2009 , third, I calculate terminal value by assuming the latest residual incoinc of 24.00 CHF per share as a perpetuity, and fourth, I set the implicd value cqual to the average stock price for the inonth of June $(847.95 \mathrm{CHF})$ and solve for the internal rate of return. The process yiclds a cost of eapital-estinate of $6.72 \%$ for

the Forbo (jroup. 